\title{
JENIS MAKNA PADA NOVEL AYAHKU (BUKAN) PEMBOHONG KARYA TERE LIYE
}

\author{
Haris Kusumandari, Ursula Dwi Oktaviani, Sri Astuti \\ Program Studi Pendidikan Bahasa dan Sastra Indonesia STKIP Persada Khatulistiwa \\ hariskusumandari08@gmail.com
}

\begin{abstract}
ABSTRAK
Penelitian ini bertujuan untuk mendeskripsikan jenis makna diantaranya makna leksikal dan gramatikal, makna referensial dan nonreferensial, makna denotatif dan konotatif, makna kata dan makna istilah, makna konseptual dan makna asosiatif, makna idiomatikal dan peribahasa, makna kias, makna lokusi, ilokusi dan perlokusi pada novel Ayahku (Bukan) Pembohong karya Tere Liye. Penelitian ini menggunakan pendektan kualitatif berbentuk deskriptif. Data penelitian ini berupa satu buah novel dengan menggunakan dokumen sebagai teknik pengumpulan data kemudian, peneliti klasifikasi kedalam jenis-jenis makna. Berdasarkan analisis di dalam novel Ayahku (Bukan) Pembohong karya Tere Liye terdapat 716 kata atau kalimat yang mengandung makna leksikal, 376 kalimat yang mengandung makma gramatikal, 716 kata atau kalimat yang mengandung makna referensial, 197 makna atau kalimat yang mengandung makna nonreferensial, 716 kata atau kalimat yang mengandung makna denotatif, 109 kata atau kalimat yang mengandung makna konotatif, 42 kata atau kalimat yang mengandung makna kata, 129 kata atau kalimat yang mengandung makna istilah, 716 kata atau kalimat yang mengandung makna konseptual, 17 kata atau kalimat yang mengandung makna asosiatif, 101 kata atau kalimat yang mengandung makna idiomatikal , 5 kalimat yang mengandung makna peribahasa, 48 kalimat yang mengandung makna kias, 14 kalimat yang mengandung makna lokusi, 14 kalimat yang mengandung makna lokusi, 14 kalimat yang mengandung makna perlokusi dari 31 sub bab. Untuk dapat melihat kemungkinan adanya jenis makna dalam novel karya Tere Liye, diperlukan adanya penelitian lanjutan dalam novel yang berbeda.
\end{abstract}

Kata kunci: Jenis Makna

\begin{abstract}
ABATRACT
This research aims to describe the types of meaning such as lexical and grammatical meaning, referential an non-referential meaning, denotative and conotative meaning, word meaning and figurative meaning, locutionary, and perlocutionary meaning in the novel Ayahku (Bukan) Pembohong by Tere Liye. This research employed qualitative approach in the form of descriptive research. The data used werea novel in which the data were collected though documentation. The researcher then classified the data into some types of meanings. Based on the analysis
\end{abstract}


from the data there were 716 words or sentences containing lexical meaning, 376 sentences containing grammatical meaning, 716 words or sentences containing referential meaning, 197 words or sentences containing non-referential meaning, 716 words or sentences containing denotative meaning, 109 words or sentences containing conotative meaning, 42 words or sentences containing word meaning, 129 words or sentences containing terminology meaning, 716 words or sentences containing conceptual meaning, 17 words or sentences containing asosiative meaning, 101 words or sentences containing idiomatic meaning, 5 sentences containing proverbial meaning, 48 sentences containing figurative meaning, 14 sentences containing ilocutionary meaning, 14 sentences containing locutionary meaning, and 14 sentences containing perlocutionary meaning from 31 sub headings. It is suggested to conduct further research to the other novel by Tere Liye to see its types of meaning.

Key words: Types of meaning

\section{PENDAHULUAN}

Bahasa merupakan lambang yang berbentuk bunyi ujar yang digunakan sebagai alat untuk menyampaikan sesuatu ide, pikiran, hasrat dan keinginan kepada orang lain. Karena lambang-lambang itu mengacu pada suatu konsep, ide, atau pikiran bahwa bahasa itu mempunyai makna (Ariyanti, 2012: 01). Kata semantik dalam bahasa Indonesia (Inggris: semantics) berasal dari bahasa Yunani (kata benda yang berati "tanda" atau "lambang". Kata kerjanya adalah semaino yang berarti "menandai" atau melambangkan. Semantik merupakan salah satu cabang linguistik yang mengkaji tentang makna (Sentosa, 2010: 01).

Jenis atau tipe makna dapat dibedakan berdasarkan beberapa . berdasarkan jenis semantiknya dapat dibedakan antara makana leksikan dan makna gramatikal, berdasarkan ada tidaknya referen pada sebuah kata/leksem dapat dibedakan adanya makna referensial dan makna non referensial, berdasarkan ada tidaknya nilai rasa pada sebuah kata/leksem dapat dibedakan adanya makna denotative dan makna konotatif, berdasarkan ketepatan maknanya dikenal adanya makna kata dan makna istilah atau makna umum dan makna khusus. Lalu berdasarkan kriteria lain atau sudut pandang lain dapat disebutkan adanya makna-makna asosiatif, kolokatif, reflektif, diomatik, dan sebagainya (Chaer, 2009: 59-60). 
Berdasarkan observasi pada beberapa novel terdapat beberapa makna yang dapat menimbulkan pertanyaan terkait dengan maksud dari makna tersebut. Adapun novel yang akan dijadikan objek penelitian yaitu novel yang berjudul Ayahku (Bukan) Pembohong Karya Tere Liye. Novel adalah salah satu jenis karya sastra dimana seorang peneliti mampu memunculkan sebuah kisah yang menarik selain itu, menjadi lebih menarik karena adanya keterkaitan antara yang satu dengan bagian yang lainnya sehingga sebuah novel mempunyai makna tersendiri. Peneliti novel bisa menulis lebih dari satu makna, jadi bagaimana pembaca dapat mengartikan setiap makna dalamnovel tersebut. Inilah yang menjadi alasan utama peneliti tertarik untuk menganalisis jenisjenis makna. Dengan adanya analisis ini peneliti dapat mengetahui jenis-jenis makna. Peneliti tertarik untuk melakukan penelitian pada karya sastra secara tertulis yang ada di dalam novel tersebut dimana peneliti akan meneliti jenis-jenis makna diantaranya makna leksikal dan gramatikal, makna referensial dan nonreferensial, makna denotatif dan konotatif, makna kata dan makna istilah, makna konseptual dan makna asosiatif, makna idiomatikal dan peribahasa, makna kias, makna lokusi, ilokusi dan perlokusi. Makna leksikal adalah makna yang berkaitan dengan makna yang sungguh-sungguh nyata dan sesuai dengan hasil observasi alat indra sedangkan makna gramatikal adalah makan yang berkaitan dengan makna jamak bahasa Indonesia yang menggunakan proses pengulangan.

Makna referensial adalah makna yang berkaitan dengan makna yang mempunyai referen sedangkan makna nonreferensial tidak mempunyai referen. Makna denotatif adalah makna yang berkaitan dengan sesuatu yang sebenarnya sedangkan makna konotatif merupakan makna yang tidak sebenarnya. Makna kata adalah makna yang tetap dan pasti sedangkan makna istilah merupakan gabungan kata yang dengan cermat mengungkapkan konsep, proses, keadaan secara cermat.

Makna konseptual merupakan makna yang sesuai dengan konsepnya, makna ini sama dengan makna leksikal, denotatif, dan referensial sedangkan maknaasosiatif merupakan kata yang melambangkan suatu keadaan, konsep dan prilaku. Makna idiomatikal merupakan ungkapan makna kiasan yang menyimpang dari makna sebenarnya sedangkan, peribahasa merupakan makna yang berkaitan dengan perumpamaan atau membandingkan. Makna kias merupakan makna yang mengandung pengandaian atau pengibaratan. 
Makna lokusi merupakan yang diungkapkan apa adanya, sedangkan makna ilokusi adalah makna yang dipahami oleh pendengar sebaliknya, yang dimaksud maka perlokusi adalah makna yang diinginkan oleh penutur oleh karena itu, makna lokusi, ilokusi dan perlokusi merupakan makna yang berkaitan dan situasional. Melalui analisis jenis-jenis makna, peneliti dapat mengetahui kejelasan isi makna di dalam novel tersebut sehingga peneliti dan pembaca akan lebih mudah untuk memahami maksud dari novel yang berjudul Ayahku (Bukan) Pembohong Karya Ter Liye. Novel dijadikan peneliti sebagai objek kajian dalam penelitian ini untuk dianalisis terkait jenis-jenis makna yang terkandung di dalamnya. Novel tersebut mempunyai cerita yang panjang sehingga pembaca harus memperhatikan dari awal cerita hingga akhir cerita dan keterpaduannya. Alasan peneliti menganalisis novel yang berjudul Ayahku (Bukan) Pembohong Karya Tere Liye karena data penelitian cukup tersedia, dan judul pada novel ini menarik minat peneliti karena di dalam novel penuh dengan pesan-pesan positif dan penuh dengan inspiratif yang mana cerita ini mengisahkan tentang seorang ayah yang membesarkan anaknya dengan dongeng-dongeng kehidupan yang mana dongeng tersebut merupakan pengalaman pribadi kehidupan ayahnya dimasa mudanya, seorang ayah yang menjunjung tinggi nilai kesederhanaan, dan mengajarkan kita bagaimana cara kita bersikap kepada semua orang terutama pada orang tua yang mempunyai peran penting didalam kehidupan kita.

Penelitian ini diharapkan untuk mempermudah pembaca untuk memahami sebuah makna di dalam suatu novel khususnya novel yang berjudul Ayahku (Bukan) Pembohong Karya Tere Liye. Novel ayahku bukan pembohong novel hasil karangan Tere Liye yaitu seorang pengarang yang menduduki rating tertinggi di website para pencinta buku sehingga menarik peneliti untuk meneliti buku-buku karya Tere Liye. Novel ini termasuk jenis novel populer karena novel ini menyajikan kembali rekamanrekaman kehidupan dengan tujuan pembaca untuk mengenali kembali pengalamannya. Berdasarkan observasi pada novel yang berjudul Ayahku (Bukan) Pembohong peneliti menemukan bahasa-bahasa yang sukar untuk dipahami, tentu saja hal ini akan mempersulit pembaca dalam memahami isi bacaan novel yang berjudul Ayahku (Bukan) Pembohong Karya Tere Liye. Berdasarkan uraian tersebut peneliti sangat tertarik untuk meneliti jenis-jenis makna yang digunakan dalam penelitian novel Ayahku (Bukan) Pembohong Karya Tere Liye. Penelitian ini diimplementasikaan 
pada bidang pendidikan tingkat SMA kelas XI Semester ganjil dan merujuk pada Kurikulum 2013 atau K13 yang mana materi ini masuk dalam KD 3.5 yaitu membandingkan karakteristik prosa lama dan baru serta mengapresiasinya dan KD 3.6 menginterpretasikan isi prosa lama dan prosa baru.

\section{METODE PENELITIAN}

Metode penelitian "adalah cara yang digunakan oleh peneliti dalam mengumpulkan data penelitianya" (Arikunto, 2013: 203). Pendekatan yang digunakan dalam penelitian ini adalah pendekatan kualitatif. Sugiyono (2015: 09) menyatakan bahwa "penelitian kualitatif adalah metode penelitian yang berlandaskan pada filsafat postpositivisme, digunakan untuk meneliti pada kondisi obyek yang alamiah, (sebagai lawanya adalah eksperimen) dimana peneliti adalah sebagai instrumen kunci, teknik pengumpulan data dilakukan secara triangulasi (gabungan), analisis data bersifat induktif/kualitatif, dan hasil penelitian kualitatif lebih menekankan makna dari pada generalisasi. Berdasarkan rumusan masalah dan tujuan penelitian maka metode penelitian yang digunakan adalah metode deskriptif. Metode deskriptif adalah metode yang menggunakan cara ilmiah dengan mendeskripsikan atau menjelaskan dengan kalimat tanpa memperhitungkan angka-angka. Metode ini digunakan untuk memperoleh gambaran jenis-jenis makna yang terdiri dari, makna leksikal dan gramatikal, makna referensial dan nonreferensial, makna denotatif dan konotatif, makna kata dan makna istilah, makna konseptual dan makna asosiatif, makna idiomatikal dan peribahasa, makna kias, makna lokusi, ilokusi dan perlokusi dalam novel Ayahku (Bukan) Pembohong Karya Tere Liye sehingga bentuk penelitian yang digunakan dalam penelitian ini adalah penelitian kepustakaan (studi pustaka).

\section{PEMBAHASAN}

Pengamatan yang dilakukan pada novel Ayahku (Bukan) Pembohong karya Tere Liye yaitu dengan membaca dan menganalisis novel tersebut kemudian peneliti menggunakan encoding (pengkodean) dan kartu data yang bertujuan untuk mempermudah proses analisis. Peneliti mengelompokan jenis makna dimasing masing bab novel tersebut, adapun hasil pengamatan penelitian sebagai berikut: 
1. Makna Leksikal Pada Sub Judul 1 Zas dan Qon (MLABPZDQ05)

Kata "Ayah" merupakan makna leksikal makna yang sebenarnya kata "Ayah" menunjukan seorang laki-laki yang sudah mempunyai seorang anak dan menjadi pemimpin didalam keluarga dan kata "Ayah" di dalam novel ini menjelaskan bahwa panggilan seorang istri kepada suaminya dan Dam sebagai anak kemudian dam menikah dengan taani mereka memanggil "ayah" karna ayah seorang pemimpin didalam keluarga.

Tabel 1. Makna Leksikal Pada Sub judul I Zaz dan Qon (MLABPZDQ05)

\begin{tabular}{|c|c|c|c|}
\hline No & Kata & Pembahasan & Halaman \\
\hline 1 & Ayah & $\begin{array}{l}\text { Ayah menunjukan seorang laki-laki yang sudah } \\
\text { mempunyai anak dan menjadi pemimpin } \\
\text { keluarga }\end{array}$ & 5 \\
\hline
\end{tabular}

2. Deskripsi Makna Gramatikal Pada Sub Judul 1 Zas dan Qon (MGABPZDQ05) Kata "Cerita-cerita" memiliki makna gramatikal karena cerita-cerita menunjukkan bahwa cerita ini lebih dari satu. Di dalam novel ini menjelaskan bahwa Dam berhenti mempercayai cerita-cerita Ayah ketika umurku dua puluh tahun.

Tabel 2. Makna Gramatikal Pada Sub Judul 1 Zaz dan Qon (MGABPZDQ05)

\begin{tabular}{cccc}
\hline No & Kalimat & \multicolumn{1}{c}{ Pembahasan } & Halaman \\
\hline 1 & $\begin{array}{l}\text { Cerita- } \\
\text { cerita }\end{array}$ & $\begin{array}{l}\text { Kata cerita-cerita menunjukkan bahwa } \\
\text { cerita ini lebih dari satu cerita }\end{array}$ & 5 \\
\hline
\end{tabular}

3. Deskripsi Makna Referensial Pada Sub Judul 1 Zas dan Qon (MRABPZDQ05) Kata "Gelas" merupakan makna referensial makna yang sebenarnya kata "Gelas" menunjukkan wadah air yang digunakan seseorang untuk minum di dalam novel ini kata "Gelas" digunakan untuk minum yang dimana gelas tersebut diambil oleh Zas dan Qon yang akan diberikan kepada kakeknya yang dimana kakeknya merupakan Ayahnya Dam. 
Tabel 3. Makna Referensial Pada Sub Judul 1 Zaz dan Qon (MRABPZDQ05)

\begin{tabular}{ccccc}
\hline No & Kata & \multicolumn{2}{c}{ Pembahasan } & Halaman \\
\hline 1 & Gelas & $\begin{array}{l}\text { Gelas menunjukan wadah air yang } \\
\text { digunakan orang untuk minum }\end{array}$ & 5 \\
\hline
\end{tabular}

4. Makna Nonreferensial Pada Sub Judul 1 Zas dan Qon (MNABPZDQ05)

Kata "dan" memiliki makna nonreferensial karena merupakan kata penghubung sebuah kalimat. Di dalam novel ini dijelaskan bahwa Zas dan Qon Harus segera tidur. Kata "yang" memiliki makna nonreferensial karena merupakan kata penghubung sebuah kalimat. Di dalam novel ini dijelaskan bahwa Zas dan Qon harus segera tidur besok mereka haru bangun pagi-pagi, serta bertumpuk alasan yang lainya mulai yang masuk akan dan dibuat-buat.

Tabel 4. Makna Nonreferensial Pada Sub Judul 1 Zaz dan Qon (MNABPZDQ05)

\begin{tabular}{cclccc}
\hline No & Kata & \multicolumn{3}{c}{ Pembahasan } & Halaman \\
\hline 1 & Dan & $\begin{array}{l}\text { Dan merupakan } \\
\text { sebuah kalimat }\end{array}$ & kata & penghubung & 10 \\
\hline
\end{tabular}

5. Makna Denotatif Pada Sub Judul 1 Zas dan Qon (MDABPZDQ05)

Kata "Gelas" merupakan makna denotatif makna yang sebenarnya kata "Gelas" menunjukan wadah air yang digunakan seseorang untuk minum di dalam novel ini kata "Gelas" digunakan untuk minum yang dimana gelas tersebut diambil oleh Zas dan Qon yang akan diberikan kepada kakeknya yang dimana kakeknya merupakan Ayahnya Dam.

Tabel 5. Makna Denotatif Pada Sub Judul 1 Zaz dan Qon (MDABPZDQ05)

\begin{tabular}{cccccc}
\hline No & Kata & \multicolumn{2}{c}{ Pembahasan } & Halaman \\
\hline 1 & Gelas & $\begin{array}{l}\text { Gelas menunjukan wadah } \\
\text { digunakan orang untuk minum }\end{array}$ & yang & 5 \\
\hline
\end{tabular}


6. Makna Konotataif Pada Sub Judul 1 Zas dan Qon (MKABPZDQ05)

Kalimat "Kode itu bilang dengan tegas" kalimat ini memiliki makna konotatif karena merupakan kalimat yang tidak sebenarnya. Maksud dari kalimat tersebut adalah sebuah kode yang merupakan sebuah larangan yang sangat tegas. Di dalam novel ini menjelaskan bahwa istri Dam memberikan kode dibalik buku tebal. Kode itu bilang tegas biarkan ayah menikmati sedikit waktu dengan kedua cucu menggemaskanya.

Tabel 6. Makna Konotatif Pada Sub Judul 1 Zaz dan Qon (MKABPZDQ05)

\begin{tabular}{|c|c|c|c|}
\hline No & Kalimat & Pembahasan & Halaman \\
\hline 1 & $\begin{array}{l}\text { Kode itu } \\
\text { bilang } \\
\text { dengan } \\
\text { tegas }\end{array}$ & $\begin{array}{l}\text { Maksud dari kalimat di samping ada } \\
\text { sebuah kode yang merupakan sebuah } \\
\text { larangan yang sangat tegas }\end{array}$ & 5 \\
\hline
\end{tabular}

7. Makna Kata Pada Sub Judul 1 Zas dan Qon (MKTABPZDQ05)

Kalimat "Bertumpuk alasan" memiliki makna kata karena makna kata itu baru menjadi jelas kalau sudah digunakan di dalam suatu kalimat. Maksud kalimat tersebut kata "bertumpuk" biasanya digunakan untuk benda atau barang barang tetapi makna bertumpuk dapat memiliki imbuhan kaya "alasan". Jadi, memiliki arti banyak alasan. Di dalam novel inii menjelaskan bahwa Zas dan Qon harus segera tidur, besok mereka harus bangun pagi-pagi, serta bertumpuk alasan lainnya, mulai dari yang masuk akal hingga yang dibuat-buat.

Tabel 7. Makna Kata Pada Sub Judul 1 Zaz dan Qon (MKTABPZDQ05)

\begin{tabular}{cclc}
\hline No & Kalimat & \multicolumn{1}{c}{ Pembahasan } & Halaman \\
\hline 1 & Bertumpuk & Kata "bertumpuk" biasanya digunakan & 5 \\
& alasan & $\begin{array}{l}\text { untuk benda atau barang tetapi makna } \\
\text { bertumpuk dapat memiliki arti yang }\end{array}$ & \\
& & berbeda ketika memiliki imbuhan kaya & \\
& & "alasan". Jadi, memiliki arti banyak \\
& alasan & \\
\hline
\end{tabular}


8. Makna Istilah Pada Sub Judul 1 Zas dan Qon (MITABPZDQ05)

Kata "Uban" memiliki makna istilah karena makna istilah disebut juga makna yang pasti, jelas dan tidak meragukan. Maksud kalimat tersebut adalah sebuah rambut sudah memutih. Di dalam novel ini menjelaskan bahwa Zas dan Qon semangat mencabuti uban kakeknya.

Tabel 8. Makna Istilah Pada Sub Judul 1 Zaz dan Qon (MITABPZDQ05)

\begin{tabular}{cccc}
\hline No & Kata & \multicolumn{1}{c}{ Pembahasan } & Halaman \\
\hline 1 & Uban & $\begin{array}{l}\text { Maksud kata di samping adalah rambut } \\
\text { sudah memutih }\end{array}$ & 5 \\
\hline
\end{tabular}

9. Makna Konseptual Pada Sub Judul 1 Zas dan Qon (MKOABPZDQ05)

Kata "Gelas" merupakan makna konseptual makna yang sebenarnya kata "Gelas" menunjukan wadah air yang digunakan seseorang untuk minum didalam novel ini kata "Gelas" digunakan untuk minum yang dimana gelas tersebut diambil oleh Zas dan Qon yang akan diberikan kepada kakeknya yang dimana kakeknya merupakan Ayahnya Dam.

Tabel 9. Makna Konseptual Pada Sub Judul 1 Zaz dan Qon (MKOABPZDQ05)

\begin{tabular}{cccc}
\hline No & Kata & Pembahasan & Halaman \\
\hline 1 & Gelas & $\begin{array}{l}\text { Gelas menunjukan wadah air yang } \\
\text { digunakan orang untuk minum }\end{array}$ & 5 \\
\hline
\end{tabular}

10. Makna Asosiatif Pada Sub Judul 1 Zas dan Qon (MAABPZDQ05)

Kalimat "Pemain super" memiliki makna asosiatif karena makna asosiatif adalah makna yang digunakan untuk melambangkan sesuatu misalnya warna merah melambangkan berani. Maksud kalimat tersebut adalah melambangkan pemain yang memiliki kemampuan yang lebih diantara yang lain. Di dalam novel ini menjelaskan bahwa meskipun benar pemain super berbakat itu dikenal ramah dan bersahaja. 
Tabel 10. Makna Asosiatif Pada Sub Judul 1 Zaz dan Qon (MAABPZDQ05)

\begin{tabular}{cllc}
\hline No & Kalimat & \multicolumn{1}{c}{ Pembahasan } & Halaman \\
\hline 1 & $\begin{array}{l}\text { Pemain } \\
\text { super }\end{array}$ & $\begin{array}{l}\text { Kata pemain super melambangkan } \\
\text { pemain yang memiliki kemampuan yang } \\
\text { lebih diantara yang lain }\end{array}$ & 7 \\
\hline
\end{tabular}

11. Makna Idiomatikal Pada Sub Judul 1 Zas dan Qon (MIDABPZDQ05)

Kalimat "Monster kecil yang suka bermain bola" kalimat ini memiliki makna Idiomatikal karena merupakan satuan-satuan bahasa yang maknanya tidak diramalkan dari makna leksikal maupun gramatikal. Maksud dari kalimat tersebut adalah menceritakan dua anak yang suka bermain bola yaitu Zas dan Qon. Di dalam novel ini menjelaskan bahwa kakek bilang kepada Zas dan Qon bahwa dirumah kita ada dua monster kecil yang suka bermain bola, yang mengidolakan klub terhebat, dan pemain terhebat didunia. Dan kalian tahu apa yang si Nomor Sepuluh katakan setelah mendengar itu? Si Nomor Sepuluh bilang, dia tidak sabar ingin sekali berkunjung menemui kalian. Ayah kembali tertawa.

Tabel 11. Makna Idiomatikal Pada Sub Judul 1 Zaz dan Qon (MIDABPZDQ05)

\begin{tabular}{cllcc}
\hline No & \multicolumn{1}{c}{ Kalimat } & \multicolumn{2}{c}{ Pembahasan } & Halaman \\
\hline 1 & $\begin{array}{l}\text { Monster kecil } \\
\text { yang suka } \\
\text { bermain bola }\end{array}$ & $\begin{array}{l}\text { Maksud kalimat di samping } \\
\text { menceritakan dua orang anak yang } \\
\text { suka bermain bola yaitu Zas dan } \\
\text { Qon }\end{array}$ & 6 \\
\hline
\end{tabular}

12. Makna Peribahasa Pada Sub Judul 7 Berdamai (MPABPB60)

Kalimat "Kolam renang sepi airnya seperti kaca tanpa riak" kalimat tersebut memiliki makna peribahasa karena makna yang masih dapat ditelusuri. Maksud kalimat tersebut kolam yang airnya tenang ibarat kaca yang jernih tanpa gelembung udara. Di dalam novel ini menjelaskan bahwa kolam renang sepi, airnya seperti kaca tanpa riak semili pun. 
Tabel 12. Makna Peribahasa Pada Sub Judul 1 Zaz dan Qon (MPABPZDQ05)

\begin{tabular}{cllc}
\hline No & \multicolumn{1}{c}{ Kalimat } & \multicolumn{1}{c}{ Pembahasan } & Halaman \\
\hline 1 & Kolam & Maksud dari kalimat di samping adalah & 68 \\
renang sepi & kolam yang airnya tenang ibarat kaca & \\
& $\begin{array}{l}\text { airnya } \\
\text { seperti kaca } \\
\text { tanpa riak }\end{array}$ & & \\
& & & \\
\hline
\end{tabular}

13. Makna Kias Pada Sub Judul 1 Zas dan Qon (MKSABPZDQ05)

Kalimat "Hadapanku mendengung" memiliki makna kias karena kias adalah makna yang diperindah atau dipercantik. Maksud kalimat tersebut adalah tatapan yang tidak memiliki tujuan hanya tatapan. Di dalam novel ini menjelaskan bahwa kepalaku mendadak kosong, laptop di hadapanku mendengung pelan.

Tabel 13. Makna Kias Pada Sub Judul 1 Zaz dan Qon (MKSABPZDQ05)

\begin{tabular}{cclc}
\hline No & Kalimat & \multicolumn{1}{c}{ Pembahasan } & Halaman \\
\hline 1 & $\begin{array}{l}\text { Hadapanku } \\
\text { mendengung }\end{array}$ & $\begin{array}{l}\text { Maksud kata di samping adalah tatapan } \\
\text { yang tidak memiliki tujuan hanya } \\
\text { tatapan kosong }\end{array}$ & 7 \\
\hline
\end{tabular}

14. Deskripsi Makna Lokusi Pada Sub Judul 1 Zas dan Qon (MLABPZDQ05)

Kalimat "Zas dan Qon tertarik" memiliki makna Lokusi karena lokusi adalah makna yang dinyatakan dalam ujaran. Maksud kalimat tersebut adalah Zas dan Qon berminat pada sesuatu atau suka. Di dalam novel ini menjelaskan bahwa rahasia apa? Zas dan Qon tertarik tidak ada anak-anak di atas dunia yang tidak tertarik dengan rahasia.

Tabel 14. Makna Lokusi Pada Sub Judul 1 Zaz dan Qon (MLABPZDQ05)

\begin{tabular}{cllc}
\hline No & Kalimat & \multicolumn{1}{c}{ Pembahasan } & Halaman \\
\hline 1 & $\begin{array}{l}\text { Zas } \\
\text { dan Qon } \\
\text { tertarik }\end{array}$ & $\begin{array}{l}\text { Makna lokusi pada kalimat di samping } \\
\text { adalah zaz dan kon berminat pada } \\
\text { sesuatu atau suka }\end{array}$ & 6 \\
\hline
\end{tabular}


15. Deskripsi Makna Ilokusi Pada Sub Judul 1 Zas dan Qon (MIABPZDQ05)

Kalimat "Zas dan Qon tertarik" memiliki makna ilokusi karena ilokusi adalah makna yang dipahami oleh pendengar. Maksud kalimat tersebut adalah Zas dan Qon berminat pada sesuatu atau suka. Di dalam novel ini menjelaskan bahwa rahasia apa? Zas dan Qon tertarik tidak ada anak-anak di atas dunia yang tidak tertarik dengan rahasia.

Tabel 15. Makna Ilokusi Pada Sub Judul 1 Zaz dan Qon (MILABPZDQ05)

\begin{tabular}{cllc}
\hline \multirow{2}{*}{ No } & Kalimat & \multicolumn{3}{c}{ Pembahasan } & Halaman \\
\hline 1 & Zas & Makna ilokusi pada kalimat di samping & 6 \\
& dan & adalah ketika pendengar salah memahami & \\
& Qon & maka makna kalimat tersebut bisa menjadi & \\
& tertarik & $\begin{array}{l}\text { Zas dan Qon tertarik oleh susuatu benda atau } \\
\text { tarikan dari suatu benda }\end{array}$ & \\
\hline
\end{tabular}

16. Deskripsi Makna Perlokusi Pada Sub Judul 1 Zas dan Qon (MPABPZDQ05)

Kalimat "Zas dan Qon tertarik" memiliki makna perlokusi karena perlokusi adalah makna yang diinginkan si penutur. Maksud kalimat tersebut adalah Zas dan Qon berminat pada sesuatu atau suka. Di dalam novel ini menjelaskan bahwa rahasia apa? Zas dan Qon tertarik tidak ada anak-anak di atas dunia yang tidak tertarik dengan rahasia.

Tabel 16. Makna Perlokusi Pada Sub Judul 1 Zaz dan Qon (MPABPZDQ05)

\begin{tabular}{|c|c|c|c|}
\hline No & Kalimat & Pembahasan & Halaman \\
\hline 1 & $\begin{array}{l}\text { Zas dan } \\
\text { Qon } \\
\text { tertarik }\end{array}$ & $\begin{array}{l}\text { Makna perlokusi pada kalimat di } \\
\text { samping adalah Zas dan Qon memiliki } \\
\text { perasaan suka pada sesuatu }\end{array}$ & 6 \\
\hline
\end{tabular}

\section{PENUTUP}

Berdasarkan hasil penelitian mengenai jenis makna pada novel Ayahku (Bukan) Pembohong karya Tere Liye maka dapat disimpulkan sebagai berikut: 
1. Makna leksikal dan makna gramatikal yang terdapat dalam novel Ayahku (Bukan) Pembohong karya Tere Liye terdapat 716 kata atau kalimat yang mengandung makna leksikal dari 31 sub bab salah satunya, yaitu kata "ayah" yang menunjukkan seorang laki-laki yang sudah mempunyai anak dan menjadi pemimpin keluarga. Terdapat 376 kata atau kalimat yang mengandung makma gramatikal dari 31 sub bab salah satunya yaitu kalimat "cerita-cerita" yang menunjukkan bahwa cerita ini lebih dari satu cerita.

2. Makna referensial dan nonreferensial dalam novel Ayahku (Bukan) Pembohong karya Tere Liye terdapat 716 kata kata atau kalimat yang mengandung makna referensial dari 31 sub bab salah satunya, yaitu "gelas" yang memiliki arti wadah air yang digunakan untuk minum. Terdapat 197 makna atau kalimat yang mengandung makna nonreferensial dari 31 sub bab salah satunya, yaitu kata "dan" yang merupakan kata penghubung sebuah kalimat.

3. Makna denotatif dan konotatif dalam novel Ayahku (Bukan) Pembohong karya Tere Liye terdapat 716 kata atau kalimat yang mengandung makna denotatif dari 31 sub bab salah satunya, kata "tangan" yang menunjukkan organ tubuh yang digunakan untuk memegang benda. Terdapat 109 kata atau kalimat yang mengandung makna konotatif dari 31 sub bab salah satunya, kalimat "kode itu bilang dengan tegas" yang memiliki arti bahwa terdapat sebuah kode yang merupakan sebuah larangan yang sangat tegas".

4. Makna kata dan makna istilah dalam novel Ayahku (Bukan) Pembohong karya Tere Liye terdiri dari 42 kata atau kalimat yang mengandung makna kata dari 31 sub bab yang mana pada sub bab 3, 5, 17, 19, 29 dan 30 tidak terdapat kata atau kalimat yang mengandung makna kata. Salah satu makna kata yaitu "bertumpuk alasan" yang mana maksud dari kalimat ini biasanya digunakan untuk benda atau barang tetapi, makna bertumpuk dapat memiliki arti yang berbeda ketika memiliki imbuhan "alasan" sehingga mempunyai arti banyak alasan. Terdapat 129 kata atau kalimat yang mengandung makna istilah dari 31 sub bab yang mana pada sub bab 31 tidak terdapat kata atau kalimat yang mengandung makna istilah. Salah satu makna istilah yaitu kata "kode", maksud kata tersebut adalah sebuah isyarat.

5. Makna konseptual dan makna asosiatif dalam novel Ayahku (Bukan) Pembohong karya Tere Liye terdapat 716 kata atau kalimat yang mengandung makna 
konseptual dari 31 sub bab salah satunya kata "televisi" yang merupakan benda elektronik yang dapat memunculkan gambar. Terdapat 17 kata atau kalimat yang mengandung makna asosiatif dari 31 sub bab yang mana pada sub bab 2, 5, 6, 7, 8, $9,10,11,14,18,21,26,29,30,31$ tidak terdapat kata atau kalimat yang mengandung makna asosiatif. Salah satu makna asosiatif yaitu kalimat "catatan emas" kalimat ini melambangkan sebuah catatan yang sangat berharga.

6. Makna idiomatikal dan peribahasa dalam novel Ayahku (Bukan) Pembohong karya Tere Liye terdapat 101 kata atau kalimat yang mengandung makna idiomatikal dari 31 sub bab salah satunya kalimat "monster kecil yang suka bermain bola" yang memiliki arti dua orang anak yang suka bermain bola yang tingkahnya seperti monster. Terdapat 5 kalimat yang mengandung makna peribahasa dari 31 sub bab yang mana pada sub bab 1, 2, 3, 4, 5, 6, 8, 10, 11, 12, 13, 15, 19, 20, 21, $22,23,24,25,26,27,28,29,30$ dan 31 tidak terdapat kalimat yang menganndung makna peribahasa. Salah satu makna kalimat peribahasa yaitu "sambil menyelam minum air" yang memiliki arti menegerjakan dua atau tiga pekerjaan sekaligus.

7. Makna kias dalam novel Ayahku (Bukan) Pembohong karya Tere Liye terdapat 48 kalimat yang mengandung makna kias dari 31 sub bab yang mana pada sub bab 3, 9, 18, 27, 28 dan 31 tidak terdapat kalimat yang mengandung makna kias. Salah satu makna kias yaitu "kebencian itu berguguran". Maksud dari kalimat tersebut adalah rasa benci yang sedikit demi sedikit hilang.

8. Makna lokusi, ilokusi, dan perlokusi dalam novel Ayahku (Bukan) Pembohong karya Tere Liye terdapat 14 kalimat yang mengandung makna lokusi dari $31 \mathrm{sub}$ bab yang mana pada sub bab 2, 3, 6, 7, 9, 10, 14, 15, 18, 21, 22, 24, 25, 26, 27, 28, dan 29 tidak terdapat makna yang mengandung makna lokusi. Salah satu makna lokusi yaitu "Zas dan Qon tertarik" sesuai yang di ujarkan kalimat tersebut memiliki arti bahwa Zas dan Qon berminat pada sesuatu. Terdapat 14 kalimat yang mengandung makna lokusi dari 31 sub bab yang mana pada sub bab 2, 3, 6, 7, 9, $10,14,15,18,21,22,24,25,26,27,28$, dan 29 tidak terdapat makna yang mengandung makna ilokusi. Salah satu makna ilokusi yaitu "Zas dan Qon tertarik" jika pendengar memiliki pemahaman yang berbeda kalimat tersebut memiliki arti bahwa Zas dan Qon tertarik oleh suatu benda atau tarikan dari suatu benda atau gaya. Terdapat 14 kalimat yang mengandung makna perlokusi dari 31 sub bab 
yang mana pada sub bab 2, 3, 6, 7, 9, 10, 14, 15, 18, 21, 22, 24, 25, 26, 27, 28, dan 29 tidak terdapat makna yang mengandung makna perlokusi. Salah satu makna perlokusi yaitu "Zas dan Qon tertarik" sesuai dengan yang diinginkan oleh pengujar maka arti dari kata "Zas dan Qon tertarik" adalah bahwa Zas dan Qon berminat pada sesuatu.

\section{DAFTAR RUJUKAN}

Arikunto, S. 2013. Prosedur Penelitian. Jakarta: Rineka Cipta.

Ariyanti, G. V. 2012. "Fukugoumeishi yang Terbentuk dari Makna Unsur-Unsur Pembentuknya (tinjauan semantik)". Skripsi. Jatinangor: Universitas Padjadjaran Fakultas Ilmu Budaya.

Chaer, Abdul. 2009. Pengantar Semantik bahasa Indonesia. Jakarta: Rineka Cipta.

Sentosa, N., Aibonotika, A. dan Rahayu, N. 2010. "Analisis Semantik Sinonim Tomodachi, Yuujin, dan Nakama dalam Kalimat Bahasa Jepang”. Skripsi: Riau: Universitas Riau. (http://id. Portal Garuda. Org, diakses 12 Maret 2018)

Sugiyono. 2015. Metode Penelitian Pendidikan Pendekatan Kuantitatif, Kualitatif, dan $R \& D$. Bandung: Alfabeta. 